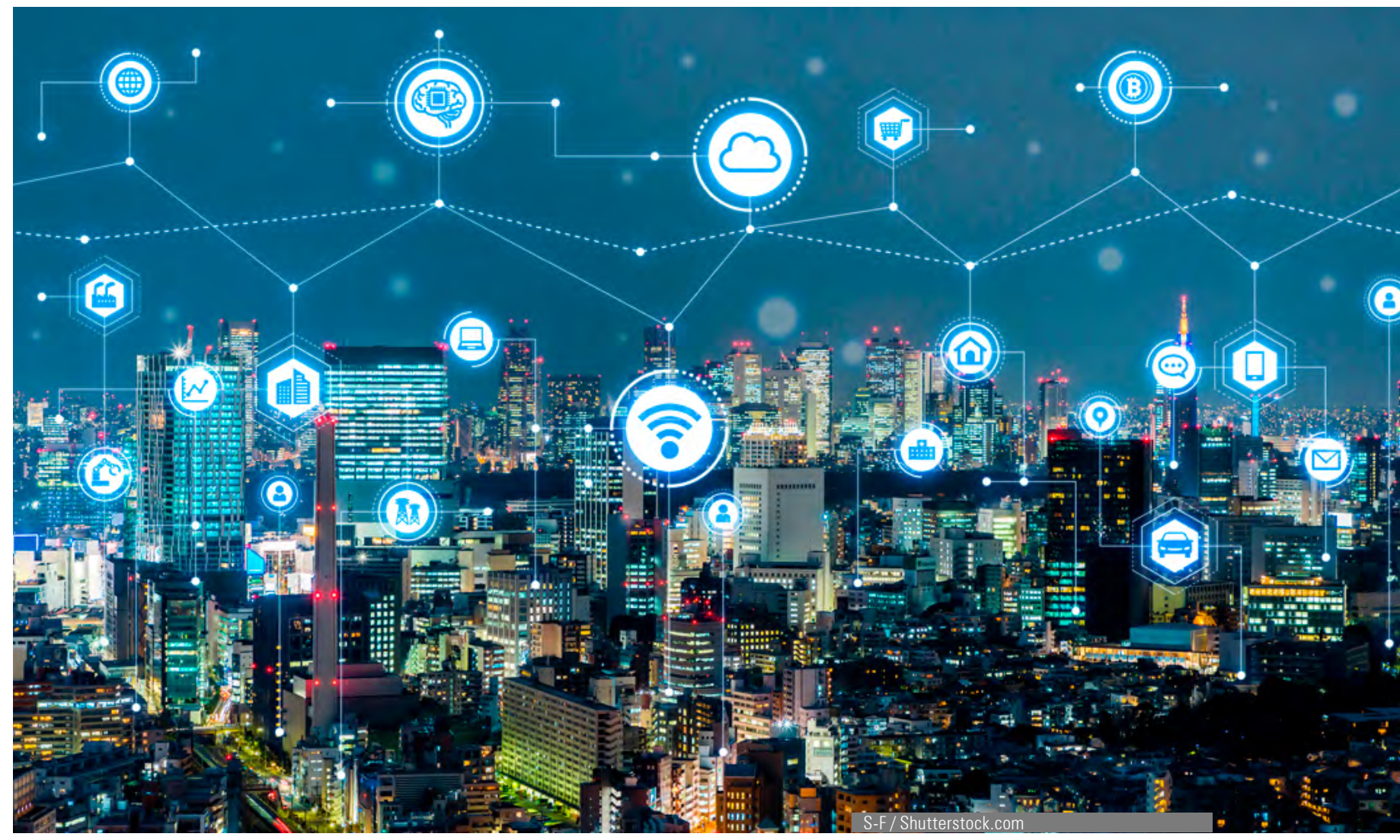

\title{
ICT Augmented Gravity Model Application: Sector Level Analysis of the Asia-Pacific Region
}

\section{Aplicación del modelo de gravedad aumentada de las TIC: análisis por sectores en la región de Asia Pacífico}

\section{Dr Bilal Mehmood}

Punjab University Center for Economics and Business Research, Pakistan

dr.bilal.eco@pu.edu.pk

https://orcid.org/0000-0003-0718-0211

Azka Arif Malik

Department of Economics, Government

College University, Pakistan

azka.arif2020@gmail.com

https://orcid.org/0000-0001-6252-254X

\section{Resumen}

El uso de las tecnologías de la información y las comunicaciones (TIC) en el comercio mejora la estructura comercial y la capacidad económica de un país. Este estudio evalúa empíricamente el impacto de las TIC en el comercio internacional en 36 países de Asia y el Pacífico a nivel sectorial entre 2007 y 2018. El estudio prueba si las TIC mejoran el comercio internacional mediante la contratación del modelo de gravedad del comercio internacional al aumentarlo con la variable TIC. Un indicador de desarrollo de las TIC (IDI) se forma uniendo siete variables TIC diferentes que muestran la infraestructura, el uso 


\section{Rabia Khalid}

School of Economics, University of the Punjab, Lahore, Pakistan

rabia.eco@pu.edu.pk https://orcid.org/0000-0003-1238-928X

Recibido: 5 de febrero 2021. Aprobado: 20 de abril 2021. Publicado: 30 de junio 2021. y las habilidades de las TIC. Al emplear la técnica de estimación de Poisson pseudo-máxima verosimilitud (PPML), este estudio muestra que las TIC mejoran el comercio al reducir los costos de transacción. Las conclusiones revelan que la tecnología de la información y las comunicaciones influye positiva y significativamente en el comercio internacional en todos los sectores de la región de Asia y el Pacífico y que el comercio se intensifica cuando ambos interlocutores comerciales tienen una alta dotación de tecnología de la información y las comunicaciones. El estudio recomienda que los gobiernos de los países en desarrollo actualicen sus niveles de infraestructura TIC.

\section{Palabras clave:}

ICT; Comercio; Modelo de gravedad; Probabilidad pseudo-máxima de Poisson (PPML).

\section{Abstract}

The use of information and communication technologies (ICT) in commerce improves the commercial structure and economic capacity of a country. This study empirically assesses the impact of ICTs on international trade in 36 countries in Asia and the Pacific, at the sectoral level, between 2007 and 2018. The study evaluates whether ICTs improve international trade by hiring the gravity model of international trade and increasing it with the ICT variable. An ICT development indicator (IDI) is formed by joining seven different ICT variables that show ICT infrastructure, use, and skills. Using the Poisson pseudo-maximum likelihood (PPML) estimation technique, this study shows that ICTs improve trade by reducing transaction costs. The findings reveal that information and communication technology positively and significantly influence international trade in all sectors of the Asia-Pacific region, and that trade intensifies when both trading partners have a high endowment of information and communications technology. The study recommends that governments in developing countries upgrade their ICT infrastructure levels.

\section{Keywords:}

ICT; Commerce; Gravity model; Poisson's pseudo-maximum probability (PPML).

\section{Introduction}

It is widely acknowledged that trade is an important factor for economic growth. For developing and least-developed countries, revenues from exports of goods and services to the global market are considered a vital source of foreign exchange as they ease pressure on the balance of payments and create employment opportunities (Abosedra \& Tang, 2019; Thangavelu \& Rajaguru 2004). While technology transfer, international competition, and economy of scale effects are apparently related to exporting, several studies note potential benefits for imports as well. In particular, studies indicate that imports of capital and intermediate goods from the Global North have a direct positive effect on the productivity of firms in the Global South through embedded high-level technology and advanced production methods (Grossman \& Helpman, 1991; McKinnon, 1964; Thangavelu \& Rajaguru, 2004). Thus, through bilateral South-North trade channels, firms in developing and least-developed countries learn to reproduce products or adopt high-level technology from trading partners in the Global North, either for sale domestically or for the global market. In an increasingly globalized environment, the trade landscape has been intensely changed and reshaped by Information and Communications 
Technology (ICT) based innovations that provide firms with access to larger markets, allowing them to expand their customer base, increase their scale, and grow their profits. It also forces firms to deal with world-class competitors, exposes them to new ideas, expertise, and encourages them to stay up to date on market trends (Lopez-Gonzalez \& Jouanjean, 2017; April \& Cradock 2000; Clarke \& Wallsten 2006; Freund \& Weinhold 2002, 2004). On the one hand, a country's infrastructure plays a critical role in creating a nurturing environment for ICT evolution and adoption. On the other hand, internet technologies provide a foundation for ongoing progress with respect to new goods and services, new markets, and new business models in the digital economy, which provide, in turn, a platform for e-commerce development. Although the growth of internet access is widely acknowledged, it creates numerous integration challenges for developing countries and least-developed countries (LDCs) to participate in e-commerce models. For instance, the International Telecommunication Union (ITU) (2015) estimated that about 4 billion people in developing countries remain offline, and only 89 million people living in LDCs use the Internet.

Globalization is surging as industries and markets become more integrated due to decreasing tariffs and trade costs, or both. The expansion of trade in Asia has been facilitated by rapid infrastructure development. Infrastructure serves as a means to integrate markets across nations. In general, infrastructure can be divided into hard and soft infrastructure. Hard infrastructure includes transportation, telecommunications, etc., whereas soft infrastructure is comprised of laws, regulations, stakeholder dialogues, etc. (Lee, 2008). Infrastructure development appears as a result of ICT revolutions, including those related to the internet and cellular mobile technology.

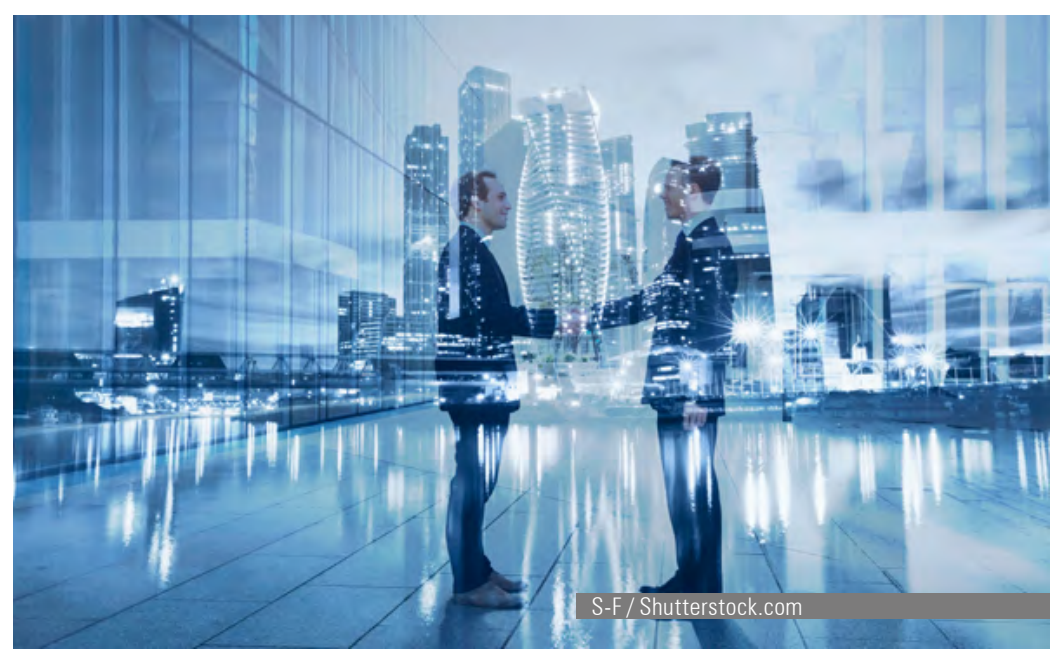

ICT use results in impressive transformations in economic development, including reductions in trade costs mainly related to ongoing technological progress, and, most importantly, ICT advances (Duval et al.,2018; Hummels, 2001). Today, it is hard to imagine the production and distribution of goods and services without ICT tools. Extraordinary advances have been made in the ICT sector over the last 14 years. ICT tools help suppliers and purchasers negotiate much more conveniently both in local markets and internationally. Thus, ICT helps control issues and enhance trade through the productive management of information flows (Demirkan et al., 2009). Specifically, ICTs allow private managers, traders, and the government to save money and time by organizing and giving form to both techniques and documentation (UNCTAD, 2006). 
Venables (2001) showed the four channels of how ICT contributes toward reductions in trade costs. First, ICT helps make the market more transparent, leading to reductions in search and communications cost. Second, ICT use reduces firms' management and monitoring costs. Third, ICT developments lower shipping costs as they save money and time by organizing and giving form to shipping methods. Fourth, ICT helps lower time in transit and associated costs. Eaton \& Kortum (2002) subsequently stated that trade between countries cannot take place without engagement and trust, and that the countries involved must overcome distances to be able to interact.

With ICT developments, geographical barriers have been reduced. As ICT helps reduce management and transaction costs, trade between countries is likely to increase despite large geographical distances between them. Moreover, Freund \& Weinhold (2004) specify two ways in which ICTs reduce trade costs. First, ICTs encourage market entry, as there is no fixed cost of entry, which enhances trade. Fixed costs include search costs, marketing and communication costs. Second, overseas transactions commonly entail advance arrangements and planning that require managing uncertainty. These uncertainties are connected with delays in receiving and passing on important information. Developments in ICT contracts enable more precise and correct planning and arrangements. Trade flows between countries increase, in consequence.

Economic growth is a necessary condition for alleviating poverty and human misery in any country. Figure 1 shows the relationship between information technology and development. Information technology combined with other factors contributes to a country's development. The use of ICT infrastructure enhances international trade by reducing trade communication costs.

Figure1: Communication Technologies in the Context of Inputs Contributing to Development

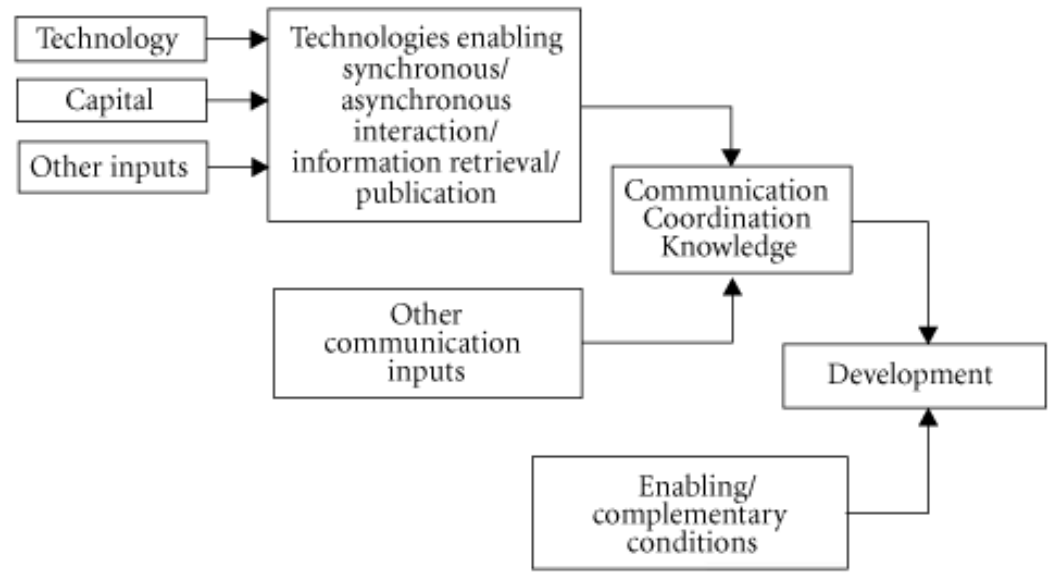

Source: ICT infrastructure in emerging Asia: Policy and regulatory roadblocks. IDRC.

The Asia-Pacific region has been at the forefront of ICT adoption since the last decade. The World Economic Forum (WEF) report reveals that seven Asia-Pacific countries (Japan, Hong Kong, China, Republic of Korea, Australia, New Zealand and Singapore) are included in the top 20 countries on the ICT readiness parameter of the Network Readiness Index. Three of these economies (Japan, New Zealand, and the Republic of Korea) are amongst the top 10 economies on the e-commerce readiness indicator as per Business-to-Consumer (B2C) E-Commerce Index published in 2016 by UNCTAD. The Republic of Korea, Singapore, and Australia were also ranked as the 
world's top three e-government leaders by the United Nations E-Government Survey in 2014. The International Telecommunication Union (ITU) 2015 ICT Development Index the measures ICT access and skills, and 4 of the top 15 countries are from this region.

The ASEAN bloc has continuously improved its ICT Development Index (IDI) score, showing its consistency as regards ICT Development. The region contains economies with different levels of development. Some have progressed more than others, but the overall picture is that all the nations in this sub-region are faring better than they did in the past. Given the importance of ICTs, the ASEAN ICT Master plan was devised in 2015. South Asian and southwest Asian countries have shown marked improvement in IDI scores. Iran, India and Myanmar have all made big gains. Iran has a better score than the global average for developing economies. India has seen massive growth in mobile internet penetration and cellular data consumption since 2016 due to a huge drop in mobile data prices.

The aggregate level trend in the progress of ICTs in Asia-Pacific developing nations presented in Figure 2 indicates that the mobile cellular subscriptions per 100 people as a standard measure of ICT expansion have risen sharply between 2001 and 2017.

\section{Figure 2: Trends in ICT Expansion in Asia-Pacific Developing Countries}

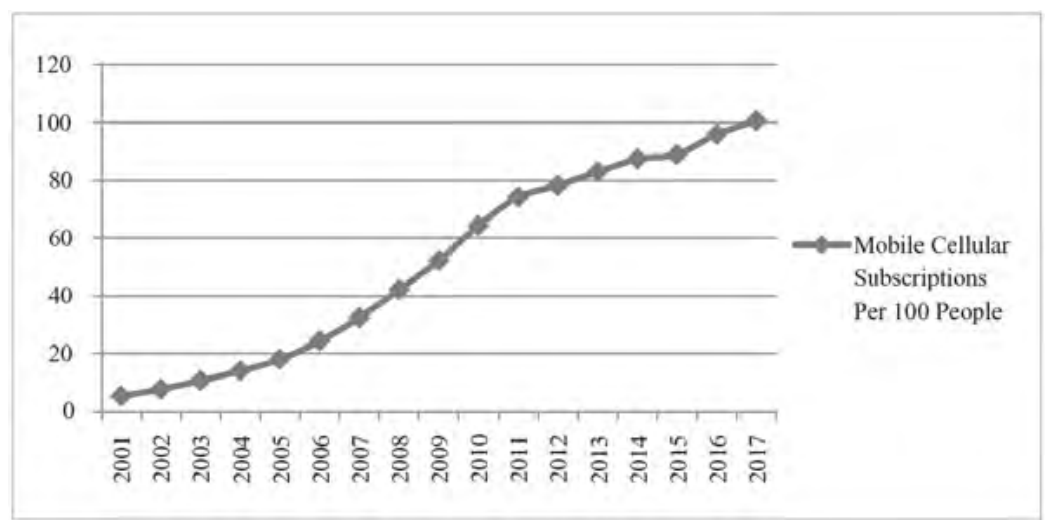

Source: World Bank (2018)

\section{Literature Review}

Literature on ICT based Gravity Models is relatively new in trade empirics. For instance, Freund \& Weinhold (2002) estimated the impact of the internet use on bilateral trade in services in a case study of developed and middle-income countries for 1995-1999. Results indicated that a 10-percent point increase in the growth of web hosts (as a proxy for Internet adoption) in a country led to an increase of 1.7 and 1.1 percent points in service exports and service imports, respectively.

Freund \& Weinhold (2004) stated that fixed costs include the costs of finding out information about the market such as advertising and establishing a distribution network. By reducing information acquisition and transmission delays, ICT use also makes planning more efficient and accurate. Fink et al. (2005) found evidence of the significant influence of communication costs on bilateral trade in the data for 107 countries in 1999. Clarke \& Wallsten (2006) found that internet access improves export performance in developing countries and that they export more to developed countries.

Tang (2006) investigated how the use of different telecommunications channels affected US imports of differentiated goods from 1975 to 2000. 
Using a fixed-effect model approach, the study found that the adoption of landline telephones, mobile phones, and internet connections in exporting countries had a significant impact on US imports of differentiated goods. Vemuri \& Siddiqi (2009) analyzed panel data for 64 countries between 1985 and 2005 and concluded that ICT infrastructure and internet availability for commercial transactions had a positive and significant impact on the volume of international trade.

Mattes et al. (2012) examined the effects of ICT availability and use on trade using data from European Union (EU) countries. Although they did not find any significant impact of ICTs on EU trade, their results suggested that trade is enhanced if both trading partners are advanced ICT users. Nath \& Liu (2013) research the impact of ICTs on imports and exports of 10 service items in 49 countries. Their findings concluded that ICT development has a significant and positive impact on international trade in the case of 6 items, namely financial services, insurance services, other business services, royalty and license fees, transportation, and travel.

Yushkova (2014) used the business internet usage index to estimate the effect of the internet on overall goods exports for 40 countries (OECD countries plus Brazil, China, India, Indonesia, Russia and South Africa) in 2011. This author found that internet usage by business communities in both exporting and importing countries was positively linked to export flows between such countries. Meijers (2014) challenged existing panel studies in which economic growth is attributed to internet use. The author improved the understanding of the mechanism by deploying a simultaneous equations model, uncovering an indirect effect of internet use on trade and of trade on economic growth.

Bensassi et al. (2015) analyzed the effect of ICT capital stock on exports from regions of Spain between 2003 and 2007 and found a positive effect. Lin (2015) reported a positive effect of internet use on trade for a sample of 200 countries between 1990 and 2006. In particular, results show that a 10\% increase in internet users increased international trade by 0.2 to $0.4 \%$. Nath \& Liu (2017) performed a disintegrated analysis by analyzing the overall impact of the ICT index on service exports and imports both separately and in consolidation. Moreover, ICT use was found to be more significant compared to ICT access and ICT skills for trade in many different services.

Barbero \& Rodriguez-Crespo (2018) studied the effect of broadband infrastructure on regional trade in the European Union and reported a positive relationship between both variables in 2007 and 2010. Latif et al., (2018) performed an analysis addressing issues of cross-sectional dependence and heterogeneity in a panel dataset for BRICS economies between 2000 and 2014. They analyzed the relationship between ICT, FDI, globalization and economic growth and found a bi-causality between ICTs and international trade. Ozcan (2018) chose Turkey to investigate the effect of ICTs on trade with its trading partners using both static and dynamic panel data models. The author found a relatively larger effect of ICTs on imports than on exports in Turkey.

Toader et al., (2018) provided insights into the consequences of the use of ICT infrastructure on the growth of economies in the European Union (EU). The findings of this study revealed that ICT infrastructure was a vital factor for economic growth along with other macroeconomic variables. Xing (2018) examined the impact of internet and e-commerce adoption on bilateral trade flows across a panel of 21 developing and least-developed countries and 30 OECD countries. Results indicated that improved access to ICT infrastructure stimulates bilateral trade in the case of developing and least-developed countries.

Erkekoğlu, \& Yilmaz (2019) empirically researched foreign trade between Turkey and 21 Asia-Pacific Economic Cooperation (APEC) member countries from 1997 to 2016 using the panel data analysis method. Using a gravity 
model, the factors influencing these countries' foreign trade were highlighted. Rodríguez-Crespo, \& Martínez-Zarzoso (2019) used a structural gravity trade model trade to quantify the effect of internet use on the aggregate trade flows of bilateral exports for 120 countries over between 2000 and 2014. They found that internet use increases trade, and that segmentation by product complexity is more sensitive to internet usage than segmentation by level of income.

Ismail (2020) researched the role of three digital dimensions (digital infrastructure, digital usage, and digital security) for trade, studying select Asian countries and 20 select trade partners between 2003 and 2017 using a gravity model. Findings revealed that digital infrastructure alone cannot facilitate trade and that intense use of digital technology by businesses and consumers and strong internet security are crucial for trade. Moreover, a narrowing digital divide in terms of internet users and security could benefit both partners to a trade transaction.

Doyar, \& Kanbir (2021) utilized the gravity model to estimate ICT trade between Turkey and its trade partners. Four models were estimated using two datasets considering internet users and cellular subscriptions. Results show that internet users and cellular subscriptions have a positive effect on both ICT exports and imports.

\subsection{Contributions of this Research:}

- To contribute to the existing literature on ICTs and international trade, this article incorporates ICTS into the gravity model of trade. It studies whether the inclusion of the ICT variables into the gravity model enhances trade on a sectoral level in the Asia-Pacific region. The following are the distinct contributions made by this research:

- This study uses the Information Development Index (IDI) instead of separate ICT variables, capturing multiple aspects of ICTs, i.e., ICT access, ICT use and ICT skills.

- A gravity model with trade barriers captured by multilateral trade resistance (MTR) is likely to yield superior estimates to one obtained without trade barriers. This study estimates 'with' and 'without' MTR assumptions and then compares both.

- The Asia-Pacific region has the greatest disparities in ICT endowment. This is made evident by IDI values that show South Korea has one of the highest IDI levels and Myanmar one of the lowest. Thus, this study has the potential for looking at the diverse structure of this regional trade bloc in its different sectors and the reasons that affect these structures.

\subsection{The ICT Development Index (IDI):}

The ICT Development Index (IDI) was designed by the International Telecommunication Union (ITU) in 2008 and was first presented in the 2009 edition of the "Measuring the Information Society Report". It was established in response to a request from ITU Member States regarding the creation of a single ICT index. The IDI ranks country performance related to ICT infrastructure and uptake. It aims to provide an objective international performance evaluation based on quantitative indicators and benchmarks. The IDI aims to capture the evolution of the information society as it moves through different stages of development including ICT readiness (infrastructure and access), ICT use (intensity), ICT capability (skills), and ICT impact (outcomes).

Although the ITU uses ten variables, this study only uses seven as data is not available for the remaining three variables for the sample countries and the time period. Table 1 shows the construction of our IDI index. Recent examples 
of work using the IDI (ICT Development Index) are Mattes et al., (2012) and Nath \& Liu, (2013).

Table 1: IDI Index Development

\begin{tabular}{|c|c|c|c|}
\hline & \multirow{2}{*}{ Variables } & \multicolumn{2}{|c|}{ Weight } \\
\hline & & in sub-group & of sub-group \\
\hline & \multicolumn{3}{|c|}{ ICT Access } \\
\hline 1 & Fixed-Telephone Lines per 100 Inhabitants & $33 \%$ & \multirow{3}{*}{$40 \%$} \\
\hline 2 & Mobile-Cellular Telephone Subscriptions per 100 Inhabitants & $33 \%$ & \\
\hline \multirow[t]{2}{*}{3} & International Internet Bandwidth (Bit/S) per Internet User & $33 \%$ & \\
\hline & ICT U: & & \\
\hline 4 & Percentage of Individuals Using the Internet & $50 \%$ & \multirow{2}{*}{$40 \%$} \\
\hline \multirow[t]{2}{*}{5} & Fixed (Wired)-Broadband Internet Subscriptions per 100 Inhabitants & $50 \%$ & \\
\hline & ICT Sk & & \\
\hline 6 & Secondary Gross Enrollment Ratio & $50 \%$ & \multirow{2}{*}{$20 \%$} \\
\hline 7 & Tertiary Gross Enrollment Ratio & $50 \%$ & \\
\hline
\end{tabular}

Source: Inspired by 'Measuring the Information Society Report', ITU.

\section{Data \& Methodology}

This study evaluates a gravity model of international trade for 8 distinct sectors in $36^{1}$ Asia-Pacific countries. To analyze the effect of ICTs on international trade, data on export values was collected in current US dollars from the UN COMTRADE database over 12 years from 2007 to 2018. Export data was collected for the eight sectors: (1) food, beverages and tobacco; (2) non-metallic mineral products; (3) machinery and transport equipment; (4) petroleum and petroleum products; (5) chemicals and chemical products; (6) clothing and textiles; (7) wood and wood products; and (8) miscellaneous products.

The influence of ICTs on trade flows is verified by the three different specifications of the gravity model primarily used by Anderson \& Van Win Coop (2003) and Baier \& Bergstrand (2007). Estimation approaches use both the traditional gravity model and one that includes MTR.

An ICT augmented gravity model without MTR is:

$$
E_{i j t}=\beta_{0}+\beta_{1} \ln \left(\operatorname{SIM}_{i j t}\right)+\beta_{2} \ln \left(D I S_{i j}\right)+\beta_{3} F_{i j}+\beta_{4} \ln \left(I C T_{i t}\right)+\beta_{5} \ln \left(I C T_{j t}\right)+\varepsilon_{i j}
$$

Where $E_{i j t}$ represents exports between two trading partners at time $(t), S M_{i j t}$ represents economic similarities between two trading countries, the distance between the capital cities of two trading countries is represented by $D I S_{i j}, F_{i j}$ represents the vector of dummy variables. (ICT $\left.T_{i t}\right)$ and $\left(I C T_{j t}\right)$ represent the extent of ICT endowments in exporter (i) and importer (j) countries respectively and $\varepsilon_{i j}$ is the bilateral error term. 
Multilateral trade resistance is added to the above equation to obtain the following functional form:

$E_{i j t}=\beta_{0}+\beta_{1} \ln \left(\operatorname{SIM}_{i j t}\right)+\beta_{2} \ln \left(D I S_{i j}\right)+\beta_{3} F_{i j}+\beta_{4} \ln \left(I C T_{i t}\right)+\beta_{5} \ln \left(I C T_{j t}\right)+\delta_{i}+$ $\delta_{j}+\gamma+\varepsilon_{i j}$

Where $\left(\delta_{i}\right)$ and $\left(\delta_{i}\right)$ are dummy variables for exporter and importer countries, which control for time-constant MTR. Additionally, $(\gamma)$ is the dummy year that captures bias stemming from deflating export data by the US price index (Anderson \& Van Win Coop, 2003).

Baier \& Bergstrand (2007) emphasized that capturing MTR with the exporter and importer effect would be adequate in a cross section but insufficient in a panel data set, so the authors recommend adding time-varying country specific effects to the panel data. A serious problem arises when certain parts of the MTR change over time. While various parts of the trade cost function, such as culture, geographic and historical elements, do not change over time, others are time-varying, like exchange rate regimes. This explains why employing a proxy for unobserved MTR by integrating only country dummy variables will capture average MTR over time but not the time-varying part. Elements that change over time become part of the error term in the equation and exhibit a consequential bias if correlated with independent variables. Thus, adding the proper time variation to the MTR is required. It should be noted that the variables that do not change bilaterally but differ between countries, meaning that, for example, population and GDP in a particular year will become correlated with MTR. Consequently, these variables cannot be included in a gravity model with time-varying trading country effects (Yushkova, 2014). The same condition applies to the ICT variables, so the effects of ICT variables are estimated as the interaction between exporter and importer ICT development.

Trading countries must therefore interact with time to then be included in the gravity model in the panel data set.

$E_{i j t}=\beta_{0}+\beta_{1} \ln \left(\operatorname{SIM}_{i j \mathrm{t}}\right)+\beta_{2} \ln \left(D I S_{i j}\right)+\beta_{3} F_{i j}+\beta_{4}\left[\ln \left(I C T_{i t}\right) \times \ln \left(I C T_{j \mathrm{t}}\right)\right]+\left(\delta_{i} \times \gamma\right)+$ $\left(\delta_{j} \times \gamma\right)+\gamma+\varepsilon_{-i j}$

Where and $\left(\delta_{i} \times \gamma\right)$ and $\left(\delta_{j} \times \gamma\right)$ are the time-varying exporter and importer dummy variables. The country dummies in interaction with time capture all time-varying exporter and importer specific effects that also comprise multilateral resistance.

\section{Estimation Results}

Prior to explaining the estimations, the following are the summary statistics for the dataset used in this paper: 
Table 2: Summary Statistics of Variables

\begin{tabular}{|c|c|c|c|c|c|c|}
\hline \multirow{2}{*}{ Variables } & \multicolumn{2}{|c|}{ Mean } & \multirow[b]{2}{*}{ Overall } & \multicolumn{3}{|c|}{ Standard Deviation } \\
\hline & Minimum & Maximum & & Minimum & Maximum & Overall \\
\hline Food, Beverages \& Tobacco & $\begin{array}{c}0.00004 \\
\text { (Timor-Leste) }\end{array}$ & $\begin{array}{l}1.007 \\
\text { (USA) }\end{array}$ & 0.1389 & $\begin{array}{c}0.000340 \\
\text { (Timor-Leste) }\end{array}$ & $\begin{array}{c}3.2748 \\
\text { (Canada) }\end{array}$ & 0.8437 \\
\hline $\begin{array}{l}\text { Non-metal minerals } \\
\text { products }\end{array}$ & $\begin{array}{l}7.05 \times 10-6 \\
\text { (Vanuatu) }\end{array}$ & $\begin{array}{l}3.2615 \\
\text { (China) }\end{array}$ & 0.3912 & $\begin{array}{l}9.50 \times 10-07 \\
\text { (Vanuatu) }\end{array}$ & $\begin{array}{c}10.3664 \\
\text { (India) }\end{array}$ & 2.7937 \\
\hline $\begin{array}{l}\text { Machinery \& transportation } \\
\text { equipment }\end{array}$ & $\begin{array}{c}0.00034 \\
\text { (Solomon Islands) }\end{array}$ & $\begin{array}{l}889.18 \\
\text { (China) }\end{array}$ & 1.0520 & $\begin{array}{c}0.00658 \\
\text { (Vanuatu) }\end{array}$ & $\begin{array}{l}2428.835 \\
\text { (China) }\end{array}$ & 712.795 \\
\hline $\begin{array}{l}\text { Petroleum \& Petroleum } \\
\text { products }\end{array}$ & $\begin{array}{c}0.000103 \\
\text { (Samoa) }\end{array}$ & $\begin{array}{l}8.8405 \\
\text { (Canada) }\end{array}$ & 3.8088 & $\begin{array}{l}2.67 \times 10-06 \\
\text { (Timor-Leste) }\end{array}$ & $\begin{array}{c}241.8454 \\
\text { (China) }\end{array}$ & 44.8139 \\
\hline $\begin{array}{l}\text { Chemicals \& Chemical } \\
\text { products }\end{array}$ & $\begin{array}{c}0.000 \quad 207 \\
\text { (Singapore) }\end{array}$ & $\begin{array}{l}12.44 \\
\text { (USA) }\end{array}$ & 1.617 & $\begin{array}{c}0.000107 \\
\text { (Solomon Islands) }\end{array}$ & $\begin{array}{l}35.9225 \\
\text { (Canada) }\end{array}$ & 11.0222 \\
\hline Clothing \& Textile & $\begin{array}{c}0.00011 \\
\text { (Vanuatu) }\end{array}$ & $\begin{array}{l}343.07 \\
\text { (China) }\end{array}$ & 18.01 & $\begin{array}{c}0.000137 \\
\text { (Solomon Islands) }\end{array}$ & $\begin{array}{l}749.162 \\
\text { (China) }\end{array}$ & 146.76 \\
\hline Wood \& Wood products & $\begin{array}{l}4.14 \times 10-09 \\
\text { (Maldives) }\end{array}$ & $\begin{array}{c}2.4730 \\
\text { (Canada) }\end{array}$ & 0.1581 & $\begin{array}{l}8.49 \times 10-08 \\
\text { (Maldives) }\end{array}$ & $\begin{array}{l}11.3548 \\
\text { (Canada) }\end{array}$ & 2.0956 \\
\hline Miscellaneous products & $\begin{array}{l}9.56 \times 10-06 \\
\text { (Solomon Islands) }\end{array}$ & $\begin{array}{c}64.1194 \\
\text { (China) }\end{array}$ & 4.1129 & $\begin{array}{c}0.000138 \\
\text { (Solomon Islands) }\end{array}$ & $\begin{array}{l}177.54 \\
\text { (China) }\end{array}$ & 34.78 \\
\hline IDI & $\begin{array}{c}0.6135 \\
\text { (Papua New Guinea) }\end{array}$ & $\begin{array}{c}8.9541 \\
\text { (Rep. of Korea) }\end{array}$ & 3.8805 & $\begin{array}{c}0.7702 \\
\text { (Canada) }\end{array}$ & $\begin{array}{c}1.0912 \\
\text { (Russian Federation) }\end{array}$ & 2.6285 \\
\hline Similarity index & $\begin{array}{l}0.5770 \\
\text { (USA) }\end{array}$ & $\begin{array}{c}1.8710 \\
\text { (Samoa) }\end{array}$ & 1 & $\begin{array}{l}0.1200 \\
\text { (USA) }\end{array}$ & $\begin{array}{c}0.7572 \\
\text { (Sri Lanka) }\end{array}$ & 0.8065 \\
\hline
\end{tabular}

Source: Authors' own calculation

Table 2 presents summary statistics for the export values of 8 sectors, the ICT index and a similarity index. Huge differences can be seen in the average value of exports of Asia-Pacific countries in eight sectors. China displays the maximum mean value for all eight groups while Solomon Islands displays the minimum mean values for five groups. The IDI shows that Papua New Guinea has the minimum level of ICT endowment while the Republic of Korea has the maximum level of average ICT endowment in Asia-Pacific countries. Samoa has the highest average while the USA displays the lowest average for the similarity index.

Empirical results of this study are presented in Tables 3 to 10, for the following:

1) Sector 1: Food, Beverages \& Tobacco.

1) Sector 2: Non-Metal Mineral Products.

2) Sector 3: Machinery \& Transport Equipment.

3) Sector 4: Petroleum \& Petroleum Products.

4) Sector 5: Chemicals \& Chemicals Products.

5) Sector 6: Clothing \& Textiles.

6) Sector 7: Wood \& Wood Products.

7) Sector 8: Miscellaneous items. 
The gravity model is employed to estimate the effects of ICT on international trade in eight different sectors. The Poison pseudo maximum likelihood (PPML) estimation technique is utilized to explore the effects of ICT on trade flows.

Specifications: This study tests the three different models: one without MTR, one with MTR and one using time-varying MTR. Model - 1 provides estimation results without controlling for MTR. Model -2 provides results partially controlled for MTR by adding trading country dummies. Model -3 provides results that control for MTR using time-varying countries dummies. The third model overcomes the bias from partially controlled multilateral resistance. However, when controlling for time-varying MTR, the exporter and importer ICT index cannot be estimated using a gravity model so ICT impacts are captured by the interaction term in the third model.

Table 3: Estimation Results of Sector 1: Food, Beverages \& Tobacco

\begin{tabular}{|c|c|c|c|}
\hline \multicolumn{4}{|c|}{ Dependent Variable: Exports } \\
\hline & Without MTR & With MTR & $\begin{array}{l}\text { With time-varying } \\
\text { MTR }\end{array}$ \\
\hline & Model - 1 & Model - 2 & Model - 3 \\
\hline $\ln (S I M)$ & $\begin{array}{l}0.1332 \\
(0.000)\end{array}$ & $\begin{array}{l}0.0591 \\
(0.060)\end{array}$ & $\begin{array}{l}0.1596 \\
(0.000)\end{array}$ \\
\hline $\ln (D I S)$ & $\begin{array}{c}-0.1169 \\
(0.001)\end{array}$ & $\begin{array}{c}-0.6368 \\
(0.000)\end{array}$ & $\begin{array}{c}-0.6556 \\
(0.000)\end{array}$ \\
\hline $\ln \left(I C T_{i}\right)$ & $\begin{array}{l}1.4985 \\
(0.000)\end{array}$ & $\begin{array}{l}0.2025 \\
(0.048)\end{array}$ & - \\
\hline $\ln \left(I C T_{j}\right)$ & $\begin{array}{l}1.6115 \\
(0.000) \\
\end{array}$ & $\begin{array}{l}0.9688 \\
(0.000) \\
\end{array}$ & - \\
\hline $\ln \left(I C T_{i}\right) \times \ln \left(I C T_{j}\right)$ & - & - & $\begin{array}{l}0.8690 \\
(0.000)\end{array}$ \\
\hline Common Language & $\begin{array}{r}-0.1822 \\
(0.009) \\
\end{array}$ & $\begin{array}{l}0.0191 \\
(0.735) \\
\end{array}$ & $\begin{array}{l}0.0772 \\
(0.194) \\
\end{array}$ \\
\hline Common Border & $\begin{array}{l}2.5777 \\
(0.000)\end{array}$ & $\begin{array}{l}0.4468 \\
(0.000)\end{array}$ & $\begin{array}{l}0.3084 \\
(0.000)\end{array}$ \\
\hline Colonial Ties & $\begin{array}{l}0.4118 \\
(0.005)\end{array}$ & $\begin{array}{l}0.3663 \\
(0.000)\end{array}$ & $\begin{array}{l}0.4798 \\
(0.000)\end{array}$ \\
\hline Same Country & $\begin{array}{c}-0.4273 \\
(0.012) \\
\end{array}$ & $\begin{array}{l}0.4713 \\
(0.000)\end{array}$ & $\begin{array}{l}0.3328 \\
(0.000) \\
\end{array}$ \\
\hline Time Fixed Effects & No & Yes & Yes \\
\hline Country Fixed Effects & No & Yes & No \\
\hline (TimexCountry) Effects & No & No & Yes \\
\hline No. of Observations & 15120 & 15120 & 15120 \\
\hline$R^{2}$ & 0.5545 & 0.9474 & 0.9449 \\
\hline
\end{tabular}

Source: Authors' estimations. Note: $p$-values in parenthesis.

Table 3 contains the estimations for the Food, Beverages \& Tobacco sector. The results of Model -1 , that does not control for MTR, show that all variables are positive and significant except the two dummy variables: same country and common language. In Model - 2, exporter and importer ICT show a positive and significant relation with trade, suggesting that ICT endowments increase international trade in the food, beverages and tobacco sector. The distance variable is negative and significant showing that trade is likely to re- 
duce as distance increases. The dummy variables have the expected positive sign except for the language dummy variable that is insignificant. The positive sign on the dummy variables shows that trade increases if countries share a common language, a common border and have past colonial ties. The insignificant relationship between the trade and language variables show trade is not influenced if both countries have the same language.

In Model - 3, exporter and importer ICT interactions have a significant positive relation suggesting that trade is improved in the food, beverages and tobacco sector of the Asia-Pacific region. This means that trade is enhanced when both the exporter and the importer have a high level of ICT development. The common language dummy variable is still insignificant in Model - 3. Additionally, the value of is low in Model -1 while it is high in Model -2 and Model -3 . The high value of in Model -2 and Model -3 evinces the high explanatory fit of the gravity model.

Table 4: Estimation Results for Sector 2: Non-Metal Mineral Products

\begin{tabular}{|c|c|c|c|}
\hline \multicolumn{4}{|c|}{ Dependent Variable: Exports } \\
\hline & Without MTR & With MTR & $\begin{array}{c}\text { With time-varying } \\
\text { MTR }\end{array}$ \\
\hline & Model - 1 & Model - 2 & Model - 3 \\
\hline $\ln (S I M)$ & $\begin{array}{l}-0.0189 \\
(0.567) \\
\end{array}$ & $\begin{array}{c}-0.00008 \\
(0.999) \\
\end{array}$ & $\begin{array}{l}0.5063 \\
(0.000)\end{array}$ \\
\hline $\ln (D I S)$ & $\begin{array}{l}-0.1768 \\
(0.000)\end{array}$ & $\begin{array}{l}-0.9165 \\
(0.000)\end{array}$ & $\begin{array}{l}-0.8403 \\
(0.000)\end{array}$ \\
\hline $\ln \left(I C T_{i}\right)$ & $\begin{array}{l}0.6378 \\
(0.000)\end{array}$ & $\begin{array}{l}0.4358 \\
(0.013) \\
\end{array}$ & - \\
\hline $\ln \left(I C T_{j}\right)$ & $\begin{array}{l}1.4704 \\
(0.000)\end{array}$ & $\begin{array}{l}1.0297 \\
(0.000)\end{array}$ & - \\
\hline $\ln \left(I C T_{i}\right) \times \ln \left(I C T_{j}\right)$ & - & - & $\begin{array}{l}0.0638 \\
(0.029)\end{array}$ \\
\hline Common Language & $\begin{array}{l}0.9619 \\
(0.000)\end{array}$ & $\begin{array}{l}1.2421 \\
(0.000)\end{array}$ & $\begin{array}{l}1.7537 \\
(0.000) \\
\end{array}$ \\
\hline Common Border & $\begin{array}{l}1.5021 \\
(0.000)\end{array}$ & $\begin{array}{l}-0.3725 \\
(0.000)\end{array}$ & $\begin{array}{l}-0.1258 \\
(0.183)\end{array}$ \\
\hline Colonial Ties & $\begin{array}{l}1.0182 \\
(0.000)\end{array}$ & $\begin{array}{l}0.6739 \\
(0.000)\end{array}$ & $\begin{array}{l}0.5381 \\
(0.000)\end{array}$ \\
\hline Same Country & $\begin{array}{l}0.3225 \\
(0.110)\end{array}$ & $\begin{array}{l}-0.5832 \\
(0.000)\end{array}$ & $\begin{array}{l}-0.8206 \\
(0.000) \\
\end{array}$ \\
\hline Time Fixed Effects & No & Yes & Yes \\
\hline Country Fixed Effects & Yes & Yes & No \\
\hline (Time $\times$ Country) Effects & No & No & Yes \\
\hline No. of Observations & 15120 & 15120 & 15120 \\
\hline$R^{2}$ & 0.1442 & 0.8290 & 0.8348 \\
\hline
\end{tabular}

Source: Authors' estimations. Note: $p$-values in parenthesis.

Table 4 shows the estimations for the Non-Metal Mineral Products sector. Model - 1 results indicate that the economic mass between two countries is negatively associated with international trade. The dummies show a positive and significant relationship except for the same country dummy. However, the ICT variables are positive and significant. Model -2 results indicate that the si- 
milarity index has no association with the trade in non-metal mineral products of Asia-Pacific countries.

The ICT indicators for both exporters and importers have a positive influence on trade. Common language and colonial ties dummy variables are found to be a significant determinant of international trade while common border and same country are not found to influence trade in this sector for the Asia-Pacific region. Model -3 results indicate that all variables are positive and significant except for the same country dummy variable. has a similar behavior as in Food, Beverages \& Tobacco.

Table 5: Estimation Results for Sector 3: Machinery \& Transport Equipment

\begin{tabular}{|c|c|c|c|}
\hline \multicolumn{4}{|c|}{ Dependent Variable: Exports } \\
\hline & Without MTR & With MTR & With time-varying MTR \\
\hline & Model - 1 & Model - 2 & Model - 3 \\
\hline $\ln (S I M)$ & $\begin{array}{l}0.0831 \\
(0.002)\end{array}$ & $\begin{array}{r}-0.0053 \\
(0.884) \\
\end{array}$ & $\begin{array}{l}0.3902 \\
(0.000)\end{array}$ \\
\hline $\ln (D I S)$ & $\begin{array}{r}-0.2050 \\
(0.000)\end{array}$ & $\begin{array}{r}-0.5450 \\
(0.000)\end{array}$ & $\begin{array}{r}-0.7000 \\
(0.000)\end{array}$ \\
\hline $\ln \left(I C T_{i}\right)$ & $\begin{array}{l}1.9383 \\
(0.000)\end{array}$ & $\begin{array}{l}1.7006 \\
(0.000)\end{array}$ & - \\
\hline $\ln \left(I C T_{j}\right)$ & $\begin{array}{l}1.7593 \\
(0.000)\end{array}$ & $\begin{array}{l}0.9923 \\
(0.000)\end{array}$ & - \\
\hline $\ln \left(I C T_{i}\right) \times \ln \left(I C T_{j}\right)$ & - & - & $\begin{array}{l}0.7367 \\
(0.000)\end{array}$ \\
\hline Common Language & $\begin{array}{r}-0.4061 \\
(0.000)\end{array}$ & $\begin{array}{l}0.1493 \\
(0.005)\end{array}$ & $\begin{array}{r}-0.7544 \\
(0.000)\end{array}$ \\
\hline Common Border & $\begin{array}{l}2.3067 \\
(0.000)\end{array}$ & $\begin{array}{l}0.8321 \\
(0.000)\end{array}$ & $\begin{array}{l}0.0566 \\
(0.639)\end{array}$ \\
\hline Colonial Ties & $\begin{array}{l}0.4698 \\
(0.000)\end{array}$ & $\begin{array}{r}-0.3241 \\
(0.000) \\
\end{array}$ & $\begin{array}{l}0.6168 \\
(0.001)\end{array}$ \\
\hline Same Country & $\begin{array}{l}0.9128 \\
(0.000)\end{array}$ & $\begin{array}{l}0.4343 \\
(0.000)\end{array}$ & $\begin{array}{l}1.8286 \\
(0.000)\end{array}$ \\
\hline Time Fixed Effects & No & Yes & Yes \\
\hline Country Fixed Effects & No & Yes & No \\
\hline (Time $\times$ Country) Effects & No & No & Yes \\
\hline No. of Observations & 15120 & 15120 & 15120 \\
\hline$R^{2}$ & 0.3627 & 0.9557 & 0.8412 \\
\hline
\end{tabular}

Source: Authors' estimations. Note: $p$-values in parenthesis.

Table 4 contains the estimations for the Machinery \& Transport Equipment sector. Model -1 shows that all variables are positive and significant except for the common language dummy variable. Model -2 results show the similarity index is negative and insignificant indicating that trade in machinery and transport equipment is not influenced if countries have a similar economic mass. ICT variables are positively related to trade. The same country dummy variable is negative while the other dummy variables show a positive and significant relationship with trade.

Model - 3 results indicate that the similarity index, ICT interactions between trading partners, and distance positively influence international trade 
showing that trade improved as these factors increased. The colonial ties and same country dummies show a positive relationship while the other two dummies, common language and common border, are negative and insignificant respectively. $R^{2}$ behaves similarly to previous sectors.

Table 6: Estimation Results for Sector 4: Petroleum \& Petroleum Products

\begin{tabular}{|c|c|c|c|}
\hline \multicolumn{4}{|c|}{ Dependent Variable: Exports } \\
\hline & Without MTR & With MTR & With time-varying MTR \\
\hline & Model - 1 & $\begin{array}{c}\text { Model } \\
-2\end{array}$ & Model - 3 \\
\hline $\ln (S I M)$ & $\begin{array}{c}-0.0662 \\
(0.043) \\
\end{array}$ & $\begin{array}{l}0.4298 \\
(0.000)\end{array}$ & $\begin{array}{l}0.7034 \\
(0.000) \\
\end{array}$ \\
\hline $\ln (D I S)$ & $\begin{array}{r}-0.2264 \\
(0.012) \\
\end{array}$ & $\begin{array}{l}-0.6538 \\
(0.000)\end{array}$ & $\begin{array}{r}-0.6458 \\
(0.000)\end{array}$ \\
\hline $\ln \left(I C T_{i}\right)$ & $\begin{array}{l}0.4521 \\
(0.000)\end{array}$ & $\begin{array}{l}0.0932 \\
(0.417)\end{array}$ & - \\
\hline $\ln \left(I C T_{j}\right)$ & $\begin{array}{l}2.6912 \\
(0.000)\end{array}$ & $\begin{array}{l}0.6269 \\
(0.000)\end{array}$ & - \\
\hline $\ln \left(I C T_{i}\right) \times \ln \left(I C T_{j}\right)$ & - & - & $\begin{array}{l}0.2214 \\
(0.000)\end{array}$ \\
\hline Common Language & $\begin{array}{r}-1.0896 \\
(0.000)\end{array}$ & $\begin{array}{l}0.2020 \\
(0.015)\end{array}$ & $\begin{array}{l}0.5625 \\
(0.000)\end{array}$ \\
\hline Common Border & $\begin{array}{l}2.5916 \\
(0.000) \\
\end{array}$ & $\begin{array}{l}1.0078 \\
(0.000) \\
\end{array}$ & $\begin{array}{l}0.7294 \\
(0.000) \\
\end{array}$ \\
\hline Colonial Ties & $\begin{array}{l}2.5916 \\
(0.007)\end{array}$ & $\begin{array}{l}0.1649 \\
(0.178)\end{array}$ & $\begin{array}{l}0.1601 \\
(0.350)\end{array}$ \\
\hline Same Country & $\begin{array}{l}1.5839 \\
(0.000) \\
\end{array}$ & $\begin{array}{l}-0.2849 \\
(0.003) \\
\end{array}$ & $\begin{array}{l}0.5033 \\
(0.000) \\
\end{array}$ \\
\hline Time Fixed Effects & No & Yes & Yes \\
\hline Country Fixed Effects & No & Yes & No \\
\hline (TimexCountry) Effects & No & No & Yes \\
\hline No. of Observations & 15120 & 15120 & 15120 \\
\hline$R^{2}$ & 0.2378 & 0.9810 & 0.9882 \\
\hline
\end{tabular}

Source: Authors' estimations. Note: $p$-values in parenthesis.

Table 6 reveals regression results for Sector 4: Petroleum \& Petroleum Products. Model -1 results are unexpected as the similarity index is negative, which indicates that trade is not influenced if countries have a similar economic mass. The language dummy variable is also negative. However, ICT variables are positive and statistically significant. Model -2 results show that exporter ICT penetration has a positive and insignificant influence on the trade of petroleum and petroleum products as trade is not enhanced by ICT advancements in exporting countries.

On the other hand, importer ICT is statistically significant. Other variables also have a positive relationship with trade except for the same country dummy, which suggests that trade is not affected if countries were once the same country. Model -3 results show that the ICT interactions between the exporter and importer are positive and significant. This indicates that trade increases when both trading countries have a high level of ICT endowments. Positive and significant dummy variables indicate that trade is increased if 
countries share a common language, a common border and same country. The colonial ties dummy is insignificant, meaning that trade is not affected by countries having shared past colonial ties.

Table 7: Estimation Results for Sector 5: Chemicals \& Chemicals Products

\begin{tabular}{|c|c|c|c|}
\hline \multicolumn{4}{|c|}{ Dependent Variable: Exports } \\
\hline & Without MTR & With MTR & With time-varying MTR \\
\hline & Model - 1 & Model - 2 & Model - 3 \\
\hline $\ln (S I M)$ & $\begin{array}{l}0.1110 \\
(0.000)\end{array}$ & $\begin{array}{l}0.1088 \\
(0.010)\end{array}$ & $\begin{array}{l}0.5238 \\
(0.000)\end{array}$ \\
\hline $\ln (D I S)$ & $\begin{array}{r}-0.3503 \\
(0.000)\end{array}$ & $\begin{array}{c}-0.6893 \\
(0.000)\end{array}$ & $\begin{array}{r}-0.8120 \\
(0.000)\end{array}$ \\
\hline $\ln \left(I C T_{i}\right)$ & $\begin{array}{l}2.0748 \\
(0.000)\end{array}$ & $\begin{array}{l}1.1113 \\
(0.000)\end{array}$ & - \\
\hline $\ln \left(I C T_{j}\right)$ & $\begin{array}{l}1.0570 \\
(0.000)\end{array}$ & $\begin{array}{l}0.4888 \\
(0.000)\end{array}$ & - \\
\hline $\ln \left(I C T_{i}\right) \times \ln \left(I C T_{j}\right)$ & - & - & $\begin{array}{l}0.4375 \\
(0.000)\end{array}$ \\
\hline Common Language & $\begin{array}{l}-0.6420 \\
(0.000)\end{array}$ & $\begin{array}{l}0.4935 \\
(0.735)\end{array}$ & $\begin{array}{r}-0.7715 \\
(0.000)\end{array}$ \\
\hline Common Border & $\begin{array}{l}2.6479 \\
(0.000)\end{array}$ & $\begin{array}{l}0.7950 \\
(0.000)\end{array}$ & $\begin{array}{l}0.0031 \\
(0.983)\end{array}$ \\
\hline Colonial Ties & $\begin{array}{l}1.1892 \\
(0.000)\end{array}$ & $\begin{array}{r}-0.0954 \\
(0.381)\end{array}$ & $\begin{array}{l}1.0456 \\
(0.007)\end{array}$ \\
\hline Same Country & $\begin{array}{c}-0.3723 \\
(0.068)\end{array}$ & $\begin{array}{r}-0.1093 \\
(0.283)\end{array}$ & $\begin{array}{l}0.9652 \\
(0.000)\end{array}$ \\
\hline Time Fixed Effects & No & Yes & Yes \\
\hline Country Fixed Effects & No & Yes & No \\
\hline (TimexCountry) Effects & No & No & Yes \\
\hline No. of Observations & 15120 & 15120 & 15120 \\
\hline$R^{2}$ & 0.4599 & 0.9307 & 0.7188 \\
\hline
\end{tabular}

Source: Authors' estimations. Note: $p$-values in parenthesis.

Table 7 contains the regression results for Sector 5: Chemicals \& Chemicals Products. Model -1 results show that all variables are positive and significant except the same country and language dummies. Model -2 results show that both exporter and importer ICT variables are positive and significant, suggesting that they enhance international trade in in chemical \& chemical products in the Asia-Pacific region. The common border dummy is found to have significant influence on international trade, but colonial ties, common language, and having been the same country do not have much influence on the trade of chemicals in Asia-Pacific countries.

The results of Model -3 indicate that ICT interactions between trading partners is positive and significant suggesting that trade in chemical \& chemical products is enhanced. The colonial ties and same country dummies have a positive relationship with trade, indicating that trade is likely to increase when countries share these characteristics. The language dummy variable negatively influences international trade in the chemicals sector. The common 
border dummy does not exhibit a significant influence on international trade in chemical \& chemical products. has a similar behavior to the previous sectors.

Table 8: Estimation Results for Sector 6: Clothing \& Textiles

\begin{tabular}{|c|c|c|c|}
\hline \multicolumn{4}{|c|}{ Dependent Variable: Exports } \\
\hline & Without MTR & With MTR & With time-varying MTR \\
\hline & Model - 1 & Model - 2 & Model - 3 \\
\hline $\ln (S I M)$ & $\begin{array}{l}0.0405 \\
(0.122)\end{array}$ & $\begin{array}{r}-0.4451 \\
(0.060)\end{array}$ & $\begin{array}{l}0.3770 \\
(0.000)\end{array}$ \\
\hline $\ln (D I S)$ & $\begin{array}{r}-0.0301 \\
(0.715)\end{array}$ & $\begin{array}{r}-0.7047 \\
(0.000)\end{array}$ & $\begin{array}{c}-0.4564 \\
(0.000)\end{array}$ \\
\hline $\ln \left(I C T_{i}\right)$ & $\begin{array}{l}0.5774 \\
(0.000)\end{array}$ & $\begin{array}{l}0.8294 \\
(0.000)\end{array}$ & - \\
\hline $\ln \left(I C T_{j}\right)$ & $\begin{array}{l}1.8597 \\
(0.000)\end{array}$ & $\begin{array}{l}0.7475 \\
(0.000)\end{array}$ & - \\
\hline $\ln \left(I C T_{i}\right) \times \ln \left(I C T_{j}\right)$ & - & - & $\begin{array}{l}0.2425 \\
(0.000)\end{array}$ \\
\hline Common Language & $\begin{array}{r}-0.5434 \\
(0.009) \\
\end{array}$ & $\begin{array}{c}0.61326 \\
(0.735)\end{array}$ & $\begin{array}{l}0.7173 \\
(0.000)\end{array}$ \\
\hline Common Border & $\begin{array}{l}2.2231 \\
(0.000)\end{array}$ & $\begin{array}{l}0.4069 \\
(0.000)\end{array}$ & $\begin{array}{l}1.0630 \\
(0.000)\end{array}$ \\
\hline Colonial Ties & $\begin{array}{l}0.3555 \\
(0.100)\end{array}$ & $\begin{array}{r}-0.5041 \\
(0.001)\end{array}$ & $\begin{array}{l}0.5199 \\
(0.007)\end{array}$ \\
\hline Same Country & $\begin{array}{l}1.3131 \\
(0.012)\end{array}$ & $\begin{array}{l}0.1563 \\
(0.072)\end{array}$ & $\begin{array}{l}0.4953 \\
(0.000)\end{array}$ \\
\hline Time Fixed Effects & No & Yes & Yes \\
\hline Country Fixed Effects & No & Yes & No \\
\hline (TimexCountry) Effects & No & No & Yes \\
\hline No. of Observations & 15120 & 15120 & 15120 \\
\hline$R^{2}$ & 0.1209 & 0.9253 & 0.9234 \\
\hline
\end{tabular}

Source: Authors' estimations. Note: p-values in parenthesis.

Table 8 displays regression results for Sector 6: Clothing \& Textiles. In Model -1 , all variables are positive and significant except the two dummies that are colonial ties and common language. In Model - 2, exporter and importer ICT indicators have a positive and significant relationship with trade, showing trade is likely to increase with ICT developments in the clothing and textile sector. The similarity index displays a negative and significant relationship with trade, suggesting that trade in the Asia-Pacific region's clothing and textile sector does not increase when both trading countries have same the economic mass. The same border and same country dummies are positively and significantly related to trade while the colonial dummy is negative and significant, and the language dummy is positive but insignificant. Model - 3 results indicated that ICT interactions between exporters and importers is positive and significant, suggesting that trade is increased in the clothing and textile sector of Asia-Pacific countries. The similarity index is positive and significant. All dummy variables have a positive and significant relation to trade except the colonial ties dummy. increases when moving from Model - 1 to Model -3 . 
Table 9: Estimation Results for Sector 7: Wood \& Wood Products

\begin{tabular}{|c|c|c|c|}
\hline \multicolumn{4}{|c|}{ Dependent Variable: Exports } \\
\hline & Without MTR & With MTR & With time-varying MTR \\
\hline & Model - 1 & Model - 2 & Model - 3 \\
\hline $\ln (S I M)$ & $\begin{array}{l}0.7418 \\
(0.000)\end{array}$ & $\begin{array}{l}0.2232 \\
(0.004)\end{array}$ & $\begin{array}{l}1.4440 \\
(0.000)\end{array}$ \\
\hline $\ln (D I S)$ & $\begin{array}{l}0.2280 \\
(0.000)\end{array}$ & $\begin{array}{l}0.6768 \\
(0.000)\end{array}$ & $\begin{array}{c}-0.3908 \\
(0.000)\end{array}$ \\
\hline $\ln \left(I C T_{i}\right)$ & $\begin{array}{l}3.0413 \\
(0.000)\end{array}$ & $\begin{array}{l}0.2079 \\
(0.358)\end{array}$ & - \\
\hline $\ln \left(I C T_{j}\right)$ & $\begin{array}{l}1.1108 \\
(0.000)\end{array}$ & $\begin{array}{l}2.1925 \\
(0.000)\end{array}$ & - \\
\hline $\ln \left(I C T_{i}\right) \times \ln \left(I C T_{j}\right)$ & - & - & $\begin{array}{l}0.4540 \\
(0.000)\end{array}$ \\
\hline Common Language & $\begin{array}{l}-0.4551 \\
(0.000)\end{array}$ & $\begin{array}{l}-0.5006 \\
(0.000)\end{array}$ & $\begin{array}{c}-0.3339 \\
(0.015)\end{array}$ \\
\hline Common Border & $\begin{array}{l}4.4724 \\
(0.000)\end{array}$ & $\begin{array}{l}1.2162 \\
(0.000)\end{array}$ & $\begin{array}{l}1.5947 \\
(0.000)\end{array}$ \\
\hline Colonial Ties & $\begin{array}{r}-1.1161 \\
(0.000)\end{array}$ & $\begin{array}{l}0.7041 \\
(0.002)\end{array}$ & $\begin{array}{l}1.7818 \\
(0.000)\end{array}$ \\
\hline Same Country & $\begin{array}{r}-3.0942 \\
(0.000)\end{array}$ & $\begin{array}{r}-0.0876 \\
(0.642)\end{array}$ & $\begin{array}{l}0.2347 \\
(0.172)\end{array}$ \\
\hline Time Fixed Effects & No & Yes & Yes \\
\hline Country Fixed Effects & No & Yes & No \\
\hline (Time $\times$ Country) Effects & No & No & Yes \\
\hline No. of Observations & 15120 & 15120 & 15120 \\
\hline$R^{2}$ & 0.7735 & 0.9438 & 0.9582 \\
\hline
\end{tabular}

Source: Authors' estimations. Note: p-values in parenthesis.

Table 9 reveals the results of regression for Sector 7: Wood \& Wood Products. Model -1 displays unexpected results as the distance variable is positive and significant which is in opposition to the theoretical background for the gravity model. The common language, same country and colonial ties also show a negative association with trade. Nevertheless, ICT variables are positive and significant. Model -2 results shows that exporter ICT penetration has a positive and insignificant influence on the trade of wood \& wood products, meaning that trade is not enhanced by the ICT advances in exporting countries.

On the other hand, importer ICT is statistically significant. Common language and same country dummy variables are considered significant determinants of international trade while the common border and colonial ties dummies are not found to influence trade in this sector of the Asia-Pacific region. Model -3 results indicate that the interaction between both countries' ICT endowments improves international trade in wood \& wood products in Asia-Pacific countries. The colonial ties and same country dummies are positively related to trade, meaning that trade is likely to increase when countries share these characteristics. The language dummy variable negatively influences international trade in wood and wood products. The common border dummy does not have a significant influence on international trade in wood 
and wood products. The increase in from Model -1 to Model -3 is relatively gradual in this case.

Table 10: Estimation Results for Sector 8: Miscellaneous Items

\begin{tabular}{|c|c|c|c|}
\hline \multicolumn{4}{|c|}{ Dependent Variable: Exports } \\
\hline & Without MTR & With MTR & With time-varying MTR \\
\hline & Model - 1 & Model - 2 & Model - 3 \\
\hline $\ln (S I M)$ & $\begin{array}{l}0.0734 \\
(0.007)\end{array}$ & $\begin{array}{l}-0.2840 \\
(0.000)\end{array}$ & $\begin{array}{l}0.2103 \\
(0.000)\end{array}$ \\
\hline $\ln (D I S)$ & $\begin{array}{c}-0.0612 \\
(0.349)\end{array}$ & $\begin{array}{c}-0.7066 \\
(0.000)\end{array}$ & $\begin{array}{l}-0.6176 \\
(0.000)\end{array}$ \\
\hline $\ln \left(I C T_{i}\right)$ & $\begin{array}{l}1.1171 \\
(0.000)\end{array}$ & $\begin{array}{l}0.8014 \\
(0.000)\end{array}$ & - \\
\hline $\ln \left(I C T_{j}\right)$ & $\begin{array}{l}2.5288 \\
(0.000)\end{array}$ & $\begin{array}{l}1.2238 \\
(0.000)\end{array}$ & - \\
\hline $\ln \left(I C T_{i}\right) \times \ln \left(I C T_{j}\right)$ & - & - & $\begin{array}{l}0.2103 \\
(0.000)\end{array}$ \\
\hline Common Language & $\begin{array}{l}-0.3948 \\
(0.001)\end{array}$ & $\begin{array}{l}0.1631 \\
(0.001)\end{array}$ & $\begin{array}{l}0.4007 \\
(0.000)\end{array}$ \\
\hline Common Border & $\begin{array}{l}2.2229 \\
(0.000)\end{array}$ & $\begin{array}{l}0.3605 \\
(0.000)\end{array}$ & $\begin{array}{l}0.2955 \\
(0.000)\end{array}$ \\
\hline Colonial Ties & $\begin{array}{l}0.5236 \\
(0.000)\end{array}$ & $\begin{array}{l}0.1664 \\
(0.219)\end{array}$ & $\begin{array}{l}0.3524 \\
(0.010)\end{array}$ \\
\hline Same Country & $\begin{array}{l}1.2184 \\
(0.000)\end{array}$ & $\begin{array}{l}-0.0950 \\
(0.231)\end{array}$ & $\begin{array}{l}0.1002 \\
(0.179)\end{array}$ \\
\hline Time Fixed Effects & No & Yes & Yes \\
\hline Country Fixed Effects & No & Yes & No \\
\hline (TimexCountry) Effects & No & No & Yes \\
\hline No. of Observations & 15120 & 15120 & 15120 \\
\hline$R^{2}$ & 0.1981 & 0.9253 & 0.9688 \\
\hline
\end{tabular}

Source: Authors' estimations. Note: $p$-values in parenthesis.

Table 10 contains regression results for Sector 8: Miscellaneous Items. In Model -1 , all variables are positive and significant except for the language variable. Model -2 results indicate that both exporter and importer ICT endowments are positively related to international trade in miscellaneous items. The similarity index is significant and negative showing countries with a similar economic mass are not likely to trade more. Colonial ties and same country dummies do not have much effect on international trade in miscellaneous items. Model -3 results indicate that all other variables are positive and significant except the same country dummy variable.

Findings conclude that ICT developments and advances in Asia-Pacific countries enhanced international trade in miscellaneous items. Additionally, a low $R^{2}$ in Model - 1 where MRTs such as fixed country and time effects are not incorporated show the model does not have a good fit. A high $\mathrm{R}^{2}$ in Model -2 and Model -3 evinces the high explanatory fit of the gravity model. 


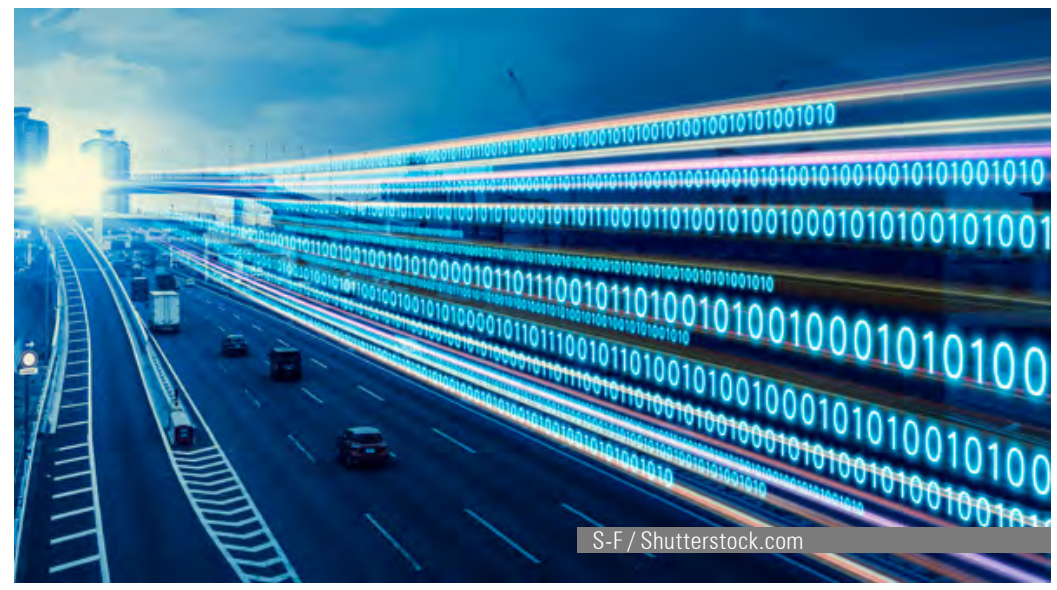

\section{Discussion:}

Overall findings of empirical estimations support of the hypothesis defined in this paper, and these findings are supported by studies like Ozcan (2018), Ismail (2020) and Doyar, \& Kanbir (2021). In Model - 1, the ICT variable has a positive and significant effect on international trade in all sectors. In Model -2 , the importer ICT variable is significant in all sectors while the exporter ICT variable is positive and insignificant for Sector 4 and Sector 7 , i.e., petroleum \& petroleum products and wood \& wood products respectively. The insignificant relationship in the petroleum sector is due to the fact that petroleum product consumption in the Asia-Pacific region is almost twice what it is in the rest of the world. The region's production capabilities are strictly limited and it consumes three times more petroleum products than it produces $(\mathrm{Wu}$, Fesharaki \& Westley, 2008).

Furthermore, OPEC countries are the world's major exporters of petroleum and petroleum products in the world due to their natural monopoly over oil extraction. The total OPEC share of world petroleum production was $43.3 \%$ in 2013. The majority of crude oil exports by OPEC members in 2013 went to Asian and Pacific countries (60.4\%). Asia-Pacific countries are the biggest importers of OPEC member petroleum products (OPEC, 2014). Kraal (2019) sheds light on the petroleum industry in certain Asian-Pacific countries. $\mathrm{He}$ stresses tax reporting transparency improvements made in Australia. For Malaysia and Indonesia, he suggests improving tax reporting transparency through the implementation of tax expenditure statements. As for Papua New Guinea, the author suggests a leaner tax incentive program for the petroleum (oil and gas) mining sector. This region does not have sufficient petroleum to export. Thus, ICTs do not have a significant impact on petroleum exports amongst exporting countries in the Asia-Pacific region.

The insignificant relation in the wood sector may be due to the fact that the Asia-Pacific region is host to the world's top ten wood product producing countries. Approximately $91 \%$ of wood production is concentrated in this region $(F A O, 2013)$. All the countries in the Asia-Pacific region are self-sufficient wood producers, so they do not export these products to each other but to other countries. Thus, ICTs do not have a significant impact on the exports of wood products amongst exporting countries of Asia-Pacific region. In Model -3 , the interaction term of the ICT variable has a positive association and is significant in all sectors, indicating that trade is enhanced when both partners have high ICT endowments.

ICT development has significant and positive effect on the exports of eight sectors in the Asia-Pacific region. The significant positive impact of IDI on 
exports from these sectors appears to suggest that ICT development has considerably enhanced market access for overseas enterprises, contributing towards improved trade flows. In other words, countries with comparatively high ICT endowments are inclined to have higher volumes of bilateral trade. These results recommend that developing the ICT infrastructure of both exporter and importer countries is vital for international trade.

The similarity index is positive in Model -1 and Model -2 for some sectors and negative in others but has a positive and significant relation towards trade flows for all sectors under Model - 3. This result suggests that economies of different sizes trade less with one another than economies of a similar size. Consequently, one may deduce that trade volumes between Australia and Canada, which are comparable in terms of GDP, will be higher than those between Canada and Fiji. Distance remains a serious barrier for trade. In all sectors, the study witnessed statistically significant negative coefficients of distance, indicating that trade diminishes with distance.

Some traditional dummy variables used by the thesis are common border, common language, colonial ties, and a shared experience of being the same country. Dummy variables shift radically subject to the sectors and estimation specifications used. However, sharing a common border, having past colonial ties, and the experience of being the same country facilitate international trade between countries, and these variables would be presumed to have a significant impact on trade. These variables can be insignificant and negative due to trade barriers and relationships of the trading partners towards each other. For example, Pakistan and India maintain a high level of mutual import. Nonetheless, contractions in both non-tariff and tariff barriers may lead to expanding the trade flows between trading countries.

\section{Conclusions}

This study used a gravity model to empirically test the hypothesis that ICTs had a positive influence on international trade in eight sectors of the Asia-Pacific region between 2007 and 2018. The results of the first and second models show that a higher level of ICT endowment in one trading country chiefly its augments international trade with other ICT-developed countries. The results highlight the importance of ICT implementation for international trade. Results of estimations under the third model indicate that ICTs add to trade when both exporter and importer have high-quality ICT penetration.

The results also show that trade flows between countries are directly linked to economic mass and inversely linked to distances between them. The common border, common language, past colonial ties, and experience of once being the same country dummy variables returned ambiguous results. The study's findings suggest that the governments of developing countries should invest in ICT infrastructure, which increases the proficiency and effectiveness of trade activities, resulting in improved trade flows. ICT investments directed towards achieving common ICT standards and cybersecurity throughout Asia-Pacific countries, so as to facilitate ICT-based trade between them.

Future research can include deployment of the 'New Heckman' estimation explained in Mnasri, \& Nechi, (2019). This will allow estimating gravity models with heteroscedasticity and zero trade values. In addition, similar research can be done in the post-covid-19 era that should return interesting results due to global effects of a pandemic where ICT use has increased like never before. 


\section{References}

- Abosedra, S., and Tang, C. F. (2019). Are exports a reliable source of economic growth in MENA countries? New evidence from the rolling Granger causality method. Empirical Economics, 56(3), 831-841.

- Anderson, J. E., and Van Wincoop, E. (2003). Gravity with gravitas: A solution to the border puzzle. National Bureau of Economic Research, 93(1), 170-192.

- Baier, S. L., and Bergstrand, J. H. (2007). Do free trade agreements actually increase members' international trade? Journal of International Economics, 71(1), 72-95.

- Baldwin, R., and Taglioni, D. (2006). Gravity for dummies and dummies for gravity equations (No. w12516). National Bureau of Economic Research. Retrieved from: http://www.nber.org/papers/w12516

- Barbero, J., Rodriguez-Crespo, E., (2018). The effect of broadband on European Union trade: a regional spatial approach. The World Economy 41(11), 2895-2913.

- Bensassi, S., Márquez-Ramos, L., Martínez-Zarzoso, I., Suárez-Burguet, C., (2015). Relationship between logistics infrastructure and trade: evidence from Spanish regional exports. Transportation Research Part-A Policy and Practice, 72, 47-61.

- Clarke, G. R., and Wallsten, S. J. (2006). Has the internet increased trade? Developed and developing country evidence. Economic Inquiry, 44(3), 465-484.

- Doyar, B. V., and Kanbir, 0. (2021, February). Can internet use and cellular subscriptions explain the ICT trade between Turkey and is trade partners within the Gravity Model? In RSEP Conferences (p. 63-72).

- Duval, Y., Utoktham, C., and Kravchenko, A. (2018). Impact of implementation of digital trade facilitation on trade costs (No. 174). ARTNeT Working Paper Series.

- $\quad$ Eaton, J., and Kortum, S. (2002). Technology, geography, and trade. Econometrica, 70(5), 1741-1779.

- Egger, P. (2000). A note on the proper specification of the gravity equation, Economics Letters, 66(1), 25-31.

- Erkekoğlu, H., and Yilmaz, B. (2019). Investigation of foreign trade between Turkey and member countries of Asia-Pacific Economic Cooperation (APEC) with gravity model. Journal of Yaşar University, 14(54), 141-151.

- Fink, C., A. Mattoo, and I.C. Neagu. 2005. Assessing the impact of communication costs on international trade. Journal of International Economics, 67(2), 428-445.

- Food and Agriculture Organization of the United Nations. 2013 Annual Report. Retrieved from: http://www. fao.org/forestry/354450e287e9c252335f2936d3cdc5b6bbd 5ff.pdf.

- Freund, C. L., and Weinhold, D. (2004). The effect of the internet on international trade. Journal of International Economics, 62(1), 171-189.

- Freund, C., and Weinhold, D. (2002). The internet and international trade in services. American Economic Review, 92(2), 236-240.

- Grossman G. M., and Helpman, E. (1991). Innovation and growth in the global economy. MIT Press, Cambridge.

- Hummels, D. (2001), Time as a trade barrier, (unpublished paper), Purdue University, West Lafayette, IN.

- Ismail, N. W. (2020). Digital trade facilitation and bilateral trade in selected Asian countries. Studies in Economics and Finance. DOI: 10.1108/SEF-10-2019-0406

- ITU, (2009). Measuring the Information Society - The ICT Development Index. Retrieved from: https://www. itu.int/pub/D-IND-ICTOI-2009

- Kraal, D. (2019). Petroleum industry tax incentives and energy policy implications: A comparison between Australia, Malaysia, Indonesia and Papua New Guinea. Energy policy, 126, 212-222.

- Latif, Z., Latif, S., Ximei, L., Pathan, Z. H., Salam, S., and Jianqiu, Z. (2018). The dynamics of ICT, foreign direct investment, globalization and economic growth: Panel estimation robust to heterogeneity and crosssectional dependence. Telematics and Informatics, 35(2), 318-328.

- Lee, S. (2008). Status and challenging issues of water infrastructure in Asia. Paper presented at First Regional Workshop on Eco-efficient Water Infrastructure in Asia, UNESCAP, 10 November 2008.

- Lin, F. (2015). Estimating the effect of the internet on international trade. The Journal of International Trade g Economic Development, 24, 409-428.

- López-González, J. and M. Jouanjean (2017), Digital trade: Developing a framework for analysis, OECD Trade, Policy Papers, No. 205, OECD Publishing, Paris.

- Mattes, A., Meinen, P., and Pavel, F. (2012). Goods follow bytes: The impact of ICT on EU trade. (no. w1182). German Institute for Economic Research, Retrieved from: http://www.diw.de/documents/publikationen/73/ diw01.c.391589.de/dp1182.pdf.

- McKinnon R. I. (1964). Foreign exchange constraints in economic development and efficient aid allocation. Economic Journal, 74, 388-409

- Meijers, H. (2014). Does the internet generate economic growth, international trade, or both? International Economics and Economic Policy, 11(1-2), 137-163.

- Mnasri, A., and Nechi, S. (2019). New approach to estimating gravity models with heteroscedasticity and zero trade values. Available at SSRN 3367440.

- Nath, H. K., and Liu, L. (2013). Information and communication technology (ICT) and trade in services: 
A disaggregated analysis. Retrieved from: http://www.shsu.edu/dot Asset/bfd272f8-df41-465e-9cbad3aabfeb6937.pdf.

- Nath, H. K., and Liu, L. (2017). Information and communications technology (ICT) and services trade. Information Economics and Policy, 41, 81-87.

- $\quad$ OPEC (2014), Annual Statistical Bulletin, Retrieved from http://www.opec.org /opecweb/static filesproject/ media/downloads/publications/ASB2014.pdf.

- Ozcan, B. (2018). Information and communications technology (ICT) and international trade: evidence from Turkey. Eurasian Economic Review, 8(1), 93-113.

- Rodríguez-Crespo, E., and Martínez-Zarzoso, I. (2019). The effect of ICT on trade: Does product complexity matter? Telematics and Informatics, 41, 182-196.

- Rose, A., and van Wincoop, E. (2001). National money as a barrier to international trade: The real case for currency union, American Economic Review, 91 (2), 386-90.

- Tang, L. (2006). Communication costs and trade of differentiated goods. Review of International Economics, 14(1), 54-68.

- Thangavelu, S. M., and Rajaguru, G. (2004). Is there an export or import-led productivity growth in rapidly developing Asian countries? a multivariate VAR analysis. Applied Economics, 36(10), 1083-1093.

- Tinbergen, Jan (1962). Shaping the World Economy: Suggestions for an International Economic Policy. New-York: The Twentieth Century Fund.

- Toader, E., Firtescu, B., Roman, A., and Anton, S. (2018). Impact of information and communication technology infrastructure on economic growth: An empirical assessment for the EU countries. Sustainability, 10(10), 3750.

- UNCTAD (2006). Information Economy Report, United Nations. Retrieved from: http://unctad.org/en/Docs/ sdteecb20061en.pdf.

- UNCTAD (2012). A practical guide to trade policy analysis. Co-published by the WTO and the United Nations Conference on Trade and Development. Retrieved from: http://vi.unctad.org/tpa/.

- Vemuri, V. K., and Siddiqi, S. (2009). Impact of commercialization of the internet on international trade: A panel study using the extended gravity model. The International Trade Journal, 23(4), 458-484.

- Venables, A. J. (2001). Geography and international inequalities: The impact of new technologies. Paper presented for World Bank Annual Conference of Development Economics, USA.

- Wu, K., Fesharaki, F., and Westley, S. B. (2008). Oil in Asia and the Pacific: Production, consumption, imports, and policy options. Paper presented at the East-West Center, US.

- Xing, Z. (2018). The impacts of Information and Communications Technology (ICT) and E-commerce on bilateral trade flows. International Economics and Economic Policy, 15(3), 565-586.

- Yushkova, E. (2014). Impact of ICT on trade in different technology groups: analysis and implications. International Economics and Economic Policy, 11(1-2), 165-177. 


\section{APPENDIX}

Table A.1. List of Asian Pacific Countries

\begin{tabular}{|c|c|c|c|c|c|}
\hline Australia & China, Hong Kong & Indonesia & Nepal & Philippines & Sri Lanka \\
\hline Bangladesh & China, Macao & Japan & New Caledonia & Rep. of Korea & Thailand \\
\hline Brunei Darussalam & Dem. Rep. of Korea & Madagascar & New Zealand & Russia Federation & Timor-Leste \\
\hline Cambodia & Fiji & Malaysia & Pakistan & Samoa & USA \\
\hline Canada & French Polynesia & Maldives & Papua New Guinea & Singapore & Vanuatu \\
\hline China & India & Mauritius & Peru & Solomon Island & Vietnam \\
\hline \multicolumn{6}{|c|}{ Excluded Countries Due to Non-Availability of Data } \\
\hline Bhutan & Burma & Comoros & Cook Island & Kiribati & Laos \\
\hline Marshall Island & Mongolia & Nauru & & & \\
\hline
\end{tabular}

\section{Technical Appendix for Gravity Model - I:}

The gravity model of international trade suggests that large economic clusters have intense interaction with each other as compared to smaller ones, and adjacent clusters attract toward each other as compared to the farther ones. The name gravity model acquired from the comparison with the Newton Theory of Gravitation (UNCTAD, 2012). The gravity model claims that volume of trade flow among trading partners is directly proportional to their economic mass and inversely proportional to the distance between them.

The groundbreaking work of Tinbergen (1962) initiated a growing theoretical and empirical literature on the gravity model of trade. The model states that the trade flow from exporter (i) to importer countries ( $j$ ) represented by $\left(T_{i j}\right)$ is directly proportional to the product of trading partners GDPs represented by $\left(Y_{i}\right)$ and $\left(Y_{i}\right)$, and inversely linked to their distance $\left(D_{i j}\right)$, mostly understood to take in all factors that might consider as trade hindrance. More generally:

$$
T_{i j}=\alpha_{0}\left(\frac{Y_{j}^{\alpha_{1}} Y_{i}^{\alpha_{2}}}{D_{i j}^{\alpha_{3}}}\right)
$$

Where $\alpha_{0}, \alpha_{2}$ and $\alpha_{3}$ are unknown parameters.

A number of variables are generally used in the gravity model to capture trade costs. Typically, empirical studies proxy trade costs with bilateral distance. However, a number of additional variables are also customarily used. These include dummies for islands, landlocked countries and common borders. To capture the all-trade barriers, Multilateral Trade Resistance (MTR) is added in the model. MTR states to the barriers, which each of country confront in their trade with all other trading countries. MTR is explained with the example as, trade between India and Pakistan is determined by the cost required to do trade with each other relative to the costs required for each of them to trade with other partners. MTR cannot be directly empirically tested. Rose \& Van Wincoop (2001) came up with a solution to overcome the problem. They used the "country-specific fixed effects" to proxy the MTR. The MTR are replaced by a vector of exporting and importing country fixed effects such as $\left(C_{i}\right)$ and $\left(C_{j}\right)$ that take the value one for trade flows between country (i) and (j) and zero otherwise.

Anderson \& Van Wincoop (2003) claimed that appropriate modelling of the MTR in the gravity model is vital for the perfect estimation. They captured the effects of MTR by utilizing the country specific effects. On the other hand, 
this method only provides the half solution to the problem of modelling MTR in a panel data set. Afterward, Baldwin \& Taglioni (2006) recommended including time changing trading partner dummies by interacting the exporter and importer countries dummies with time to eliminate the origin of bias. This specification is often used in the panel data model to control the MTR (Baier \& Bergstrand, 2007).

\section{Technical Appendix for Gravity Model - II:}

In order to convert the exports values from current US Dollar to constant US Dollar, this study utilize the weighted price index for each sector item. Due to the inaccessibility of segregated price deflator for each country, this study employed a US price deflator in accordance with the assumption that the relative price arrangements in these different sectors item are similar in all trading countries. Given that the products are exported, this assumption will not be invalid.

The following equation was used to attain sector exports in 2002 constant US Dollar.

\section{$X_{k t \text { constant }}=\frac{X_{k t}}{P_{k t}^{U S} \times E_{t}} \times P_{k, 2002}^{U S} \times E_{2002}$}

Where the constant export of sector $(k)$ in year $(t)$ represented by $X_{k t}$ constant is obtained by dividing the current export of sector $(k)$ in year $(t)$ with US price index of sector $(k)$ in year $(t)$ interacted with the current exchange rate. Afterward multiply it with constant US price index represented by $P_{k, 2002}^{U S}$ and with constant exchange rate represented by $E_{2002}$. The data on price indices is calculated from Bureau of Economic Analysis (BEA) and exchange rate data is obtained from World Development Indicators (WDI).

The independent variables are ICT index for exporting and importing country, distance, economic mass and a set of dummy variables. It is challenging to develop a single measure for ICT that exhibit all characteristics of communication technology. This study constructed IDI in accordance with ITU by uniting seven different ICT variable. The IDI index displays the infrastructure, usage and skills of ICT. The index value varies from zero to ten as zero displays the minimum level of ICT development and value ten displays the maximum level of ICT development. The data of ICT variables are obtained from ITU. The study employs a proxy for economic size such as similarity index. This index captures the economic size between two trading countries. Egger (2000) de-

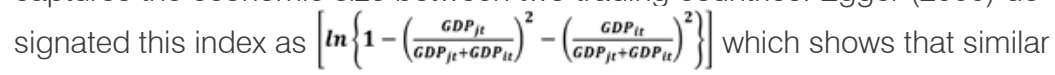
sized countries are likely to trade more with one another. The data for similarity index was taken from WDI. The distance variable in the gravity equation is measured in kilo meters between the two capitals of the trading countries.

A vector of dummy variables shows four variables that are adjacency, common language, past colonial ties and practice of once being same country. The dummies exhibit whether the two trading partners have same official language, past colonial link, common border, or chance of once being the same country. These dummies take the value one if the trading countries share the characteristics and zero if they do not. The data on dummies and distance was collected from "French Centre d'Etudes Prospectives et d'Informations Internationales" (CEPII). 